\title{
PENGARUH PENGGANTIAN TEPUNG IKAN DENGAN LIMBAH WINE ANGGUR TERFERMENTASI TERHADAP PERFORMANS BROILER
}

\author{
WIRA SUSANA, I W., I M. NURIYASA, DAN N. W. SITI \\ Faculty of Animal Husbandry, Udayana University, Denpasar \\ e-mail: yanwir4@yahoo.co.id
}

\begin{abstract}
ABSTRAK
Penelitian ini bertujuan untuk mengkaji pengaruh penggantian tepung ikan dengan limbah wine anggur terfermentasi dalam ransum terhadap performans broiler. Rancangan penelitian yang digunakan adalah rancangan acak lengkap (RAL) yang terdiri dari lima perlakuan dan lima kali ulangan. Perlakuan yang diberikan adalah ransum yang menggunakan 10\% tepung ikan, $\mathrm{O} \%$ limbah wine anggur terfermentasi (Ro), ransum yang menggunakan 7,5\% tepung ikan, 2,5\% limbah wine anggur terfermentasi (R1), ransum yang menggunakan 5\% tepung ikan, $5 \%$ limbah wine anggur terfermentasi (R2), ransum yang menggunakan 2,5\% tepung ikan, 7,5\% limbah wine anggur terfermentasi (R3), ransum tanpa (o\%) tepung ikan, 10\% limbah wine anggur terfermentasi (R4). Variabel yang diamati adalah performans meliputi; konsumsi ransum, pertambahan berat badan, berat badan akhir, dan konversi ransum. Hasil penelitian menujukkan penggantian tepung ikan dengan limbah wine anggur terfermentasi dalam ransum menunjukkan berat badan akhir, pertambahan berat badan dan konsumsi ransum pada perlakuan R1 paling tinggi dibandingkan Ro, R2, $\mathrm{R}_{3}$, dan $\mathrm{R} 4(\mathrm{P}<0,05)$. Sedangkan nilai konversi ransum berbeda tidak nyata $(\mathrm{P}>0,05)$. Berdasarkan hasil penelitian dapat disimpulkan bahwa perlakuan ransum R1 menghasilkan performans paling tinggi dibandingkan perlakuan lainnya.
\end{abstract}

Kata kunci: broiler, tepung ikan, limbah wine anggur, peformans

\section{THE EFFECT OF FISH FLOUR REPLACEMENT WITH WASTE OF FERMENTED WINE ON BROILER PERFORMANCES}

\begin{abstract}
The research aims at analyzing the effect of fish flour replacement with fermented wine waste in rations to the broiler performances. It was conducted using a Complete Random Design with 5 treatments and 5 replications.. The treatments were ration using $10 \%$ of fish flour and without (o\%) waste of fermented wine (Ro); ration using $7.5 \%$ of fish flour, and $2.5 \%$ waste of fermented wine (R1); ration using $5 \%$ of fish flour, and $5 \%$ waste of fermented wine (R2); ration using $2.5 \%$ of fish flour and $7.5 \%$ waste of fermented wine (R3); ration without (o\%) fish flour and $10 \%$ waste of fermented wine (R4). Variables observed were performance including feed consumption, body weight gain, final body weight and feed conversion. The results showed that final weight, weight gain and feed consumption was highest on R1 treatment compared to Ro, R2, R3, and R4 ( $<<0.05)$. In contrast, the value of feed conversion was similar $(\mathrm{P}>0.05)$. It can be concluded that the highest ferformance on broiler fed ration using $7.5 \%$ of fish flour, and $2.5 \%$ waste of fermented wine.

Key words: broiler, fish flour, waste of fermented wine, performance

\section{PENDAHULUAN}

Populasibroilermengalamiperkembanganyangpesat setiap tahunnya, dari tahun 2013 adalah 1.344.191.104 ekor menjadi 1.443.349.118 ekor di tahun 2014 dan pada tahun 2015 meningkat menjadi 1.497 .625 .658 ekor (Direktorat Jenderal Peternakan, 2016). Tepung ikan merupakan bahan pakan sumber protein dan mengandung semua asam amino yang dibutuhkan ayam.

Kandungan protein tepung ikan memang relatif tinggi, protein hewani tersebut disusun oleh asam-asam amino esensial yang kompleks diantaranya asam amino lisin dan methionin. Tepung ikan mempunyai kelemahan yaitu mudah busuk sehingga terjadi penurunan kadar protein kasar (Anggorodi, 1985). Bahan rusak tersebut bisa mengandung bakteri E. coli atau Salmonella yang dapat membahayakan kesehatan ternak (Guillaume et al., 2001).
\end{abstract}


Salah satu limbah industripembuatan wine berbahan anggur memiliki kandungan nutrien yang cukup sebagai bahan pakan. Harga limbah anggur murah dan tersedia secara kontinyu. Limbah wine fermentasi mengandung $78,32 \%$ bahan kering, $27,05 \%$ protein, $18,20 \%$ serat kasar, dan lemak 0,32\% (Mahardhika, 2016). BPS Buleleng (2013) melaporkan Kabupaten Buleleng merupakan sentra penghasil anggur di Bali dari total produksi buah anggur pada tahun 2013 yaitu 9,118 ton buah anggur segar, 50\% diantaranya masuk ke industri pengolahan wine.

Alcaide et al. (2008) menyatakan bahwa fermentasi limbah pembuatan wine dari anggur mampu menjadi sumber protein dan serat kasar yang cocok untuk pakan ternak ruminansia. Melalui proses fermentasi dengan EM-4 kandungan protein limbah wine dari anggur dapat ditingkatkan dari 17,79\% menjadi 27,05\% (Mahardhika, 2016).

Informasi pemanfaatan limbah wine anggur terfermentasi untuk pakan broiler sebagai pengganti tepung ikan sampai saat ini masih terbatas, sehingga perlu dilakukan penelitian untuk mengetahui performans broiler yang diberi level limbah wine anggur terfermentasi sebagai pengganti tepung ikan dalam ransum broiler.

\section{MATERI DAN METODE}

\section{Broiler}

Penelitian menggunakan broiler umur 10 hari, dengan masa adaptasi o-10 hari. Penelitian dilakukan di Desa Pesaban, Kecamatan Rendang, Kabupaten Karangasem selama 8 minggu.

\section{Kandang}

Kandang yang digunakan adalah kandang sistem battrey colony yang terbuat dari bilah- bilah bambu. Tiap petak kandang berukuran panjang $100 \mathrm{~cm}$, lebar $50 \mathrm{~cm}$, dan tinggi $50 \mathrm{~cm}$.

\section{Ransum dan Air Minum}

Bahan pakan yang digunakan dalam menyusun ransum terdiri dari tepung jagung, pollard, tepung ikan, tepung kedelai, dedak padi, tepung tapioka, dan limbah anggur fermentasi. Limbah wine anggur diperoleh dari UD Timan Agung, Kerambitan, Tabanan, Bali. Air minum yang diberikan berupa air PDAM.

\section{Rancangan Penelitian}

Rancangan acak lengkap (RAL) yang terdiri dari 5 perlakuan dan 5 kali ulangan. Perlakuan yang diberikan adalah ransum yang menggunakan $10 \%$ tepung ikan, o\% limbah wine anggur terfermentasi (Ro), ransum yang menggunakan $7,5 \%$ tepung ikan, $2,5 \%$ limbah wine anggur terfermentasi (R1), ransum yang menggunakan $5 \%$ tepung ikan, $5 \%$ limbah wine anggur terfermentasi (R2), ransum yang menggunakan 2,5\% tepung ikan, 7,5\% limbah wine anggur terfermentasi (R3), ransum tanpa (o\%) tepung ikan, 10\% limbah wine anggur terfermentasi (R4). Data yang diperoleh dianalisis dengan sidik ragam dan apabila diantara perlakuan terdapat perbedaan yang nyata $(\mathrm{P}<0,05)$ maka dilanjutkan dengan Uji Jarak Berganda Duncan dengan tingkat signifikansi 5\% (Steel dan Torrie,1991).

\section{Variabel}

Variabel yang diamati adalah performans mencakup konsumsi ransum, berat badan akhir, pertambahan berat badan, dan konversi ransum.

\section{HASIL DAN PEMBAHASAN}

Konsumsi ransum perlakuan $\mathrm{R} 4$ nyata $(\mathrm{P}<0,05)$ lebih rendah dari perlakuan Ro, R1, R2 dan R3 masingmasing sebesar $13,02 \%, 14,36 \%$, 9,75\% dan 9,52\%. Kandungan serat dalam ransum mulai meningkat dan pada ransum R4 kandungan serat mencapai $5,99 \%$ (Tabel 1).

Table 1. Performans broiler yang diberi limbah wine anggur terfermentasi

\begin{tabular}{|c|c|c|c|c|c|c|}
\hline \multirow{2}{*}{ Variabel } & \multicolumn{5}{|c|}{ Perlakuan $^{1)}$} & \multirow{2}{*}{$\mathrm{SEM}^{3)}$} \\
\hline & Ro & R1 & $\mathrm{R} 2$ & R3 & R4 & \\
\hline $\begin{array}{l}\text { Konsumsi Ransum } \\
\text { (g/ek) }\end{array}$ & $2043^{a 2)}$ & $2075^{a}$ & $1969^{a}$ & $1964^{a}$ & $1777^{b}$ & 0.047 \\
\hline PBB (g) & $1270^{a}$ & $1273^{a}$ & $1161^{b}$ & $1178^{b}$ & $1028^{c}$ & 0,028 \\
\hline BB Akhir (g) & $1446^{a}$ & $1460^{a}$ & $1351^{b}$ & $1363^{b}$ & $1235^{c}$ & 0,016 \\
\hline Konversi Ransum & $1,609^{a}$ & $1,629^{a}$ & $1,697^{a}$ & $1,667^{a}$ & $1,729^{a}$ & 0,062 \\
\hline \multicolumn{7}{|l|}{ Keterangan: } \\
\hline \multicolumn{7}{|c|}{$\begin{array}{l}\text { 1) R0: ransum yang menggunakan } 10 \% \text { tepung ikan dan tanpa ( } 0 \% \text { ) limbah wine anggur } \\
\text { terfermentasi, R1: ransum yang menggunakan } 7,5 \% \text { tepung ikan dan } 2,5 \% \text { limbah } \\
\text { wine anggur terfermentasi, R2: ransum yang menggunakan } 5 \% \text { tepung ikan dan } 5 \% \\
\text { limbah wine anggur terfermentasi, R3: ransum yang menggunakan } 2,5 \% \\
\text { tepung ikan dan } 7,5 \% \text { limbah wine anggur terfermentasi, R4: ransum tanpa (0\%) } \\
\text { tepung ikan dan } 10 \% \text { limbah wine anggur terfermentasi }\end{array}$} \\
\hline \multicolumn{7}{|c|}{$\begin{array}{l}\text { 2) Superskript yang sama pada baris yang sama menunjukkan perbedaan yang tidak } \\
\text { nyata }(P>0,05) \text { dan superskript berbeda pada baris yang sama menunjukkan per- } \\
\text { bedaan yang nyata }(P<0,05)\end{array}$} \\
\hline 3) SEM: Standard & rror of the T & Treatment & Means & & & \\
\hline
\end{tabular}

Semakin tinggi kandungan serat kasar dalam ransum maka akan mempercepat penuhnya tembolok yang menyebabkan ayam berhenti mengkonsumsi ransum. Konsumsi serat menyebabkan peningkatan waktu transit dari mulut sampai ke usus, menurunkan laju aliran asam empedu ke usus halus, sehingga akan menurunkan laju pergantian sirkulasi enterohepatik. Menurut Demigne et al. (2001) pengurangan frekuensi sirkulasi karena adanya serat akan mengurangi mekanisme penghambatan umpan balik (feed back inhibition) yang sebagian mengontrol sintesis asam empedu.

Berat badan akhir broiler yang mendapat perlakuan 
R1 lebih tinggi dibandingkan Ro sebesar 0,96\% tetapi nilai tersebut berbeda tidak nyata $(\mathrm{P}>0,05)$. Pertambahan berat badan pada pelakuan R1 lebih tinggi dibandingkan R2, R3 dan R4 sebesar 9,64\%, 8,08\% dan $23,83 \%$ dan menunjukkan perbedaan yang nyata $(\mathrm{P}<0,05)$. Tingkat konsumsi ransum pada perlakuan $\mathrm{R} 4$ paling rendah, menghasilkan berat akhir paling rendah juga. Ini sejalan dengan pendapat Aliyani (2002) bahwa berat potong ayam pedaging dipengaruhi oleh konsumsi ransum, kualitas ransum, lama pemeliharaan, dan aktivitas. Ini didukung dengan pendapat Wahju (2004) dimana konsumsi pakan yang rendah akan semakin menurunkan pula pertambahan berat badan ternak itu sendiri.

Konversi ransum perlakuan Ro sebesar 1,61 lebih rendah dibandingkan perlakuan R1 sebesar 1,24\%, R2 sebesar 5,18\%, R3 sebesar 3,47\%, dan R4 sebesar 6,94\%, namun nilai tersebut menunjukkan perbedaan tidak nyata $(\mathrm{P}>0,05)$. Nilai konversi ransum menunjukkan tingkat efisiensi penggunaan ransum untuk menghasilkan pertambahan berat badan. Wahju (2004) menyatakan bahwa konversi pakan dapat digunakan untuk mengukur efisiensi penggunaan ransum. Hal ini didukung oleh pernyataan North dan Bell (1990) bahwa angka konversi ransum yang kecil maka ransum semakin efisien karena konsumsi ransumnya digunakan secara optimal.

\section{SIMPULAN}

Berdasarkan hasil penelitian dapat disimpulkan bahwa perlakuan ransum yang menggunakan $7,5 \%$ tepung ikan dan 2,5\% limbah wine anggur terfermentasi menghasilkan performans meliputi konsumsi ransum, berat badan akhir, dan pertambahan berat badan paling tinggi dibandingkan perlakuan lainnya.

\section{UCAPAN TERIMA KASIH}

Pada kesempatan ini penulis ingin menyampaikan ucapan terima kasih kepada Dekan dan Ketua Program Pascasarjana Fakultas Peternakan Universitas Udayana beserta staf dan pegawai, atas pelayanan administrasi dan fasilitas pendukung yang diberikan dalam melakukan penelitian ini. Semoga hasil penelitian ini dapat berguna khususnya dibidang ilmu peternakan.

\section{DAFTAR PUSTAKA}

Alcaide, J., Altet, M.N., Plans, P., et al., 2008. Cigarette smoking as a risk factor for tuberculosis in young adults: a case-control study: Tuber.Lung Dis. (77):1126.

Aliyani A. 2002 Persentase Berat Karkas dan Organ Dalam Ayam Broiler yang Diberi Tepung Daun Talas (Colocaisa Esculenta L.) Dalam Ransum. Skripsi. Fakultas Pertanian, Institut Pertanian Bogor, Bogor.

Anggorodi, R. 1985. Ilmu Makanan Ternak Unggas. UIpress. Jakarta.

[BPS] Badan Pusat Statistik Kabupeten Buleleng. 2013. Produksi Buah Anggur di Kabupeten Buleleng. Sumber: http:/www.buleleng.bps.go.id. Diakses 8 Juli 2015.

Demigne, C., C. Remesy and C. Morand. 2001. Resistant Starches and Lipid Metabolism. in: Susan Cho, S. and M.L. Dreher. eds. Handbook of Dietary Fiber. pp. 155164. Marcel Decker, Inc, New York.

Direktorat Jenderal Peternakan. 2016. Populasi Ayam Pedaging Menurut Provinsi di Indonesia. Sumber: http:// ditjenak.go.id. Diakses 20 Juni 2016.

Guillaume, J., Kaushik, S., Bergot, P. and Metailer, R. 2001. Nutrition and Feeding of Fish and Crustaceans, p.169-181.

Mahardhika, A. 2016. Analisa Proksimat Limbah Wine dari Anggur. Laboratorium Nutrisi, Kelompok Kerja Penelitian Sapi Potong Grati, Jawa Timur.

Nort, M. O and D. D. Bell. 1990. Commercial Chicken Production Manual. $4^{\text {th }}$ Edition. Van Nostrand Reinhold. New York

Steel, R. G. D. and J. H. Torrie. 1991. Principle and Procedures of Statistic. Mc.Grow Hill Book Bo.Inc,New York.

Wahju, J. 2004. Ilmu Nutrisi Unggas. Cetakan Ketiga. Gajah Mada University Press, Yogyakarta. 